\title{
Analysis Effects of Exposuretime on Long Steel Stainless Steel Material Proper which Experience Stress Corrosion Cracking
}

\author{
Junaidi $^{1}$, Soni Hestukoro ${ }^{2}$, Ahmad Yanie $^{3}$, Irfansyah Siregar ${ }^{4}$, Eddy $^{5}$ \\ $\left\{*\right.$ junaidi.stth@gmail.com $\left.{ }^{1}\right\}$ \\ Department of Enginering Universitas Harapan, Medan, Indonesia ${ }^{1}$ \\ Department of Mechanical Engineering, PoliteknikNegeri Medan,Indonesia ${ }^{2}$ \\ Department of Manufacture EngineeringUniversitasAL'Azhar Medan Indonesia ${ }^{3,4,5}$.
}

\begin{abstract}
The experiment are exucuted by using the Spring Loaded Fixture type in accordance with ASTM G49 and E 292 for the experimental method and specimen geometry each. Initiation of SCC failure begins with pitting corrosion and thinning attacks to date stress reaches the highest strength Furthermore, in this case. This experiment is aimed to investigate characteristics of SCC Austenitic stainless steel AISI 304, AISI 316, and 316L in Glycerol solution with four variations of chloride concentration, namely 50,6,000, 9,000, and 12,000 ppm, two types of initial tensile stress, namely50 \% and 70\% Yield Strength from each material test, and 150Cconstant temperature. Failure occurs in catastrophic and brittle (trans granular) fractures. AISI 304 is more vulnerable to all experimental conditions. All material tests did not fail for $50 \mathrm{ppm}$ chloride concentration up to 556 hours of exposure time. The more concentration and chloride concentration is given, the crack speed becomes higher by shortening the failure time.
\end{abstract}

Keywords:Effects, Austenitic stainless steel,Stress Corrosion Cracking,characteristics

\section{$1 \quad$ Introduction}

Corrosion is derived from Latin corrodore which means "gnawing" that is degradation of material due to chemical reaction between material and its environment. Karat is part of corrosion which only happened to iron metal $(\mathrm{Fe})$ which react with environment, like water and outside air.

Discussion of corrosion involves various disciplines, such as physics, chemistry, metallurgy, electrochemistry and material engineering. The nature and shape of corrosion is always associated with all or part of the discipline. The process of corrosion in a material is unavoidable, in which we can only reduce or slow down the process. The technical approach taken in assessing corrosion properties has helped researchers to reveal in detail the characteristics and properties of corrosion, so that it has found some technologies and systems in controlling corrosion and the side effects it causes. This has been able to reduce the loss in humans. Metallurgical engineering by researchers has found a variety of material variations that are "immune" to certain corrosion in accordance with its usefulness, so that directly has contributed greatly to the industry. One form of corrosion of some form of corrosion in question is the Stress Corrosion Cracking (Cracking) which is abbreviated as "SCC". SCC is a 
specific corrosion and one of the causes of material damage that is classified as dominant in a material structure, so experts have categorized SCC failure into a cause of failure calculated in designing a construction .

Although intensive SCC research has long been done, but the results obtained to date only come to the stage of understanding of the process of the form of corrosion, while the control efforts undertaken still not give maximum results. The use of Austro-stainless Steels used in the construction of Glycerol distillation tanks and their piping is one of the cases observed. The failure occurring in this vessel for a period of time is an SCC failure. Most of the failures that occur in the welded connection area that has the largest residual stress due to the manufacturing process, such as bending and welding process. The SCC study mostly used the precracked specimen method to determine the crack growth rate against KISCC stress intensity, the elastic strain specimen using various test specimens, such as C-ring, doublebeam, O-ring to determine the correlation of failure time to the given strain, and plastic strain specimen, such as U-bend to determine the effect of plastic strain on failure time. The three methods each have advantages and disadvantages. Testing by method.precracked is done by considering the disability of the specimen, the elastic strain of the specimen will result in a decrease in stress, and the specimen strain platter is limited to test specimen that has undergone plastic deformation.

Testing with constant load method in assessing SCC problem needs to be done to find the failure characteristics due to the effect of voltage change on failure time, crack speed, and crack length. (constant load) in assessing the SCC problem needs to be done to find the failure characteristics due to the effect of voltage changes on failure time, crack speed, and crack length. Testing by this method will yield results appropriate to the conditions as the case examples mentioned above. Testing with constant load method further encourages continuous crack growth until the specimen fails and the failure occurs in complete (complete) relative to testing with elastic and plastic strain.

\section{Research Methodology}

SCC testing can basically use various forms of test specimens and is highly dependent on the purpose of testing to be achieved. The purpose of this study has been described in 1.3 above, so that the form of constant tensile load testing is deemed appropriate to obtain the graph of the test results in question. ASTM G 49.explains that the uni-axial voltage method for SCC testing gives results that are in accordance with SCC properties, and notched specimens of tensile test specimens can be used as standard materials for SCC testing.

The dimensions and geometry of the specimens as shown in Figure 1 are based on ASTM E 292 (Time for Rapture Notch Tension Test). To obtain the voltage concentration, then the specimen is given a notch. The material of the test object used has specifications as contained in Table 1 and Table 2. The table shows the mechanical properties obtained based on tensile testing performed and the chemical composition obtained from the Inspection Certificate issued by the TÜV Material Certification Agency. 


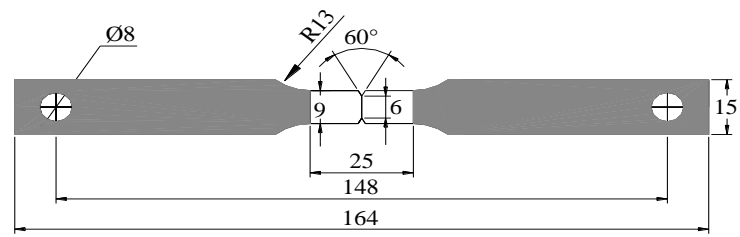

Fig. 1: Geometry of Test Material according to ASTM E 29

Table 1: Mechanical Properties of Test Tests Using ASTM E-8 Tensile Test

\begin{tabular}{|l|c|c|c|c|c|c|c|c|c|}
\hline Material & $C$ & $C r$ & Mn & Mo & N & Ni & $P$ & $S$ & $S i$ \\
\hline Type & $\%$ & $\%$ & $\%$ & $\%$ & $\%$ & $\%$ & $\%$ & $\%$ & $\%$ \\
\hline AISI304 & 0.04 & 18.3 & 2 & - & 0.03 & 8.2 & 0.045 & 0.03 & 1 \\
\hline AISI316 & 0.08 & 17.1 & 1.4 & 2.03 & 0.04 & 10.15 & 0.045 & 0.03 & 0.8 \\
\hline AISI316L & 0.025 & 16.966 & 1.209 & 2.083 & 0.047 & 10.172 & 0.028 & 0.003 & 0.316 \\
\hline
\end{tabular}

Table 2: Chemical Composition Test Objects

\begin{tabular}{lccc}
\hline Material Type & $\begin{array}{c}\boldsymbol{\sigma}_{\mathbf{s}} \\
\text { Mpa }\end{array}$ & $\begin{array}{c}\mathbf{Y}_{\mathbf{s}}(\mathbf{0 . 0 2 \%}) \\
\mathbf{M p a}\end{array}$ & El. (\%) \\
\hline AISI 304 & 674 & 442 & 55 \\
AISI 316 & 596 & 299 & 50 \\
AISI 316L & 632 & 316 & 49.3 \\
\hline
\end{tabular}

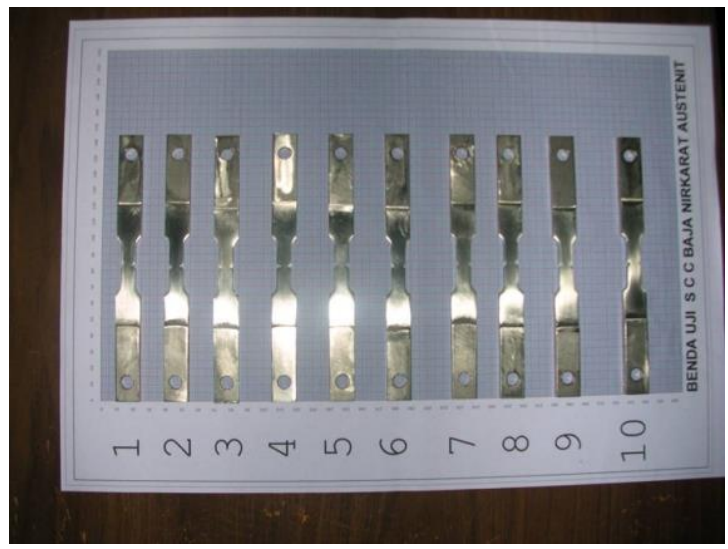

Fig. 2: Test objects used according to ASTM E 292 


\subsection{Arrangement and Setup of Test Equipment}

The design of the equipment for testing is based on the research objectives, the parameters measured and the accuracy of the test results that can be justified. Although some alternative test equipments may be used to provide a constant load according to the type of loading in this test, but some of the advantages of the equipment used in this test are relatively simpler, easier to make measurements and more easily controlled.

Constant stable and controlled constant loading will provide an increase in stress due to the decrease in cross-sectional area and due to the growth of cracks occurring in the notch area so that the ligaments will shrink. The crack propagation in this area is then measured at a certain time duration and can be performed more easily and constant load control will continue to be performed in accordance with the spring extension that occurs.

Table 3: Spring Kalibration Result Press ( Style Used )

\begin{tabular}{ccccc}
\hline Load Testing & Start Lenght & Deflection & Long end & Test \\
\hline $\mathrm{P}$ & Lo & Ys & Ls & Material \\
Kgf & $\mathrm{mm}$ & $\mathrm{mm}$ & $\mathrm{mm}$ & \\
433 & 130 & 14,5 & 115,5 & AISI 304 \\
606 & 130 & 19,8 & 110,2 & AISI 304 \\
292 & 130 & 8,6 & 121,4 & AISI 316 \\
410 & 130 & 13,7 & 116,3 & AISI 316 \\
310 & 130 & 10,3 & 119,7 & AISI316L \\
433 & 130 & 14,5 & 115,5 & AISI316L \\
\hline
\end{tabular}

Table 4 : Testing Conditions Phase I,II,IIIdan IV.

\begin{tabular}{ccccccc}
\hline \multirow{2}{*}{ Environment } & \multicolumn{5}{c}{ Materials, Spring Loading and Deflection Press } \\
\hline & \multicolumn{2}{c}{ AISI 304 } & \multicolumn{2}{c}{ AISI316 } & AISI316L \\
$7.000 \mathrm{ml}$ Glycerol + & $\mathrm{Y}_{\mathrm{s}}=442 \mathrm{MPa}$ & $\mathrm{Y}_{\mathrm{s}}=299 \mathrm{MPa}$ & $\mathrm{Y}_{\mathrm{s}}=316 \mathrm{MPa}$ \\
\cline { 2 - 7 } $50 \mathrm{ppm}$ Chloride & $50 \% \mathrm{Y}_{\mathrm{s}}$ & $70 \% \mathrm{Y}_{\mathrm{s}}$ & $50 \% \mathrm{Y}_{\mathrm{s}}$ & $70 \% \mathrm{Y}_{\mathrm{s}}$ & $50 \% \mathrm{Y}_{\mathrm{s}}$ & $70 \% \mathrm{Y}_{\mathrm{s}}$ \\
\cline { 2 - 7 } with temperatue & 433 & 606 & 293 & 410 & 310 & 433 \\
$150^{\circ} \mathrm{C}$ & Kgfand & Kgfand & Kgfand & Kgfand & Kgfand & Kgfand \\
& $14,5 \mathrm{~mm}$ & $19,8 \mathrm{~mm}$ & $8,6 \mathrm{~mm}$ & $13,7 \mathrm{~mm}$ & $10,3 \mathrm{~mm}$ & $14,5 \mathrm{~mm}$ \\
\hline
\end{tabular}




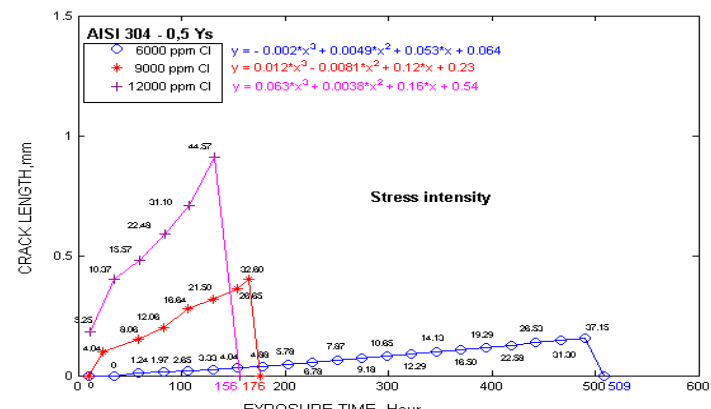

Fig.3. The correlation curve between the Exposure time and the crack length of SCC AISI 304 (specimens No. 3, 5, and 7) in different environments with an initial voltage of $0.5 \sigma$ Ys.

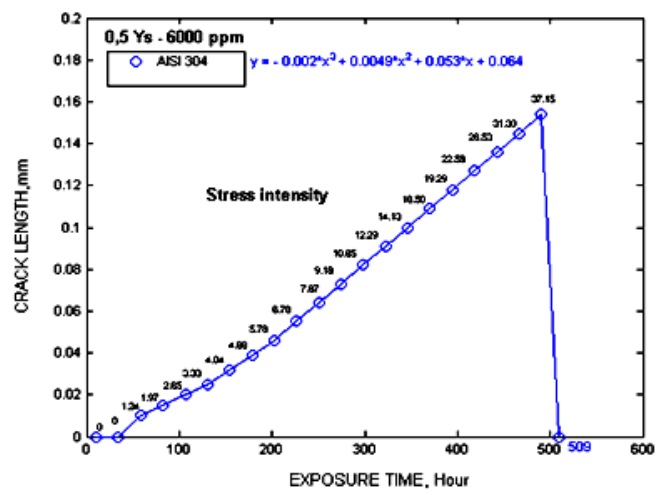

Fig. 4. Correlation curve between Exposure time and SCC crack length at $0.5 \sigma \mathrm{Ys}$ (Test object No. 3) and 6000 ppm chloride concentration with different material

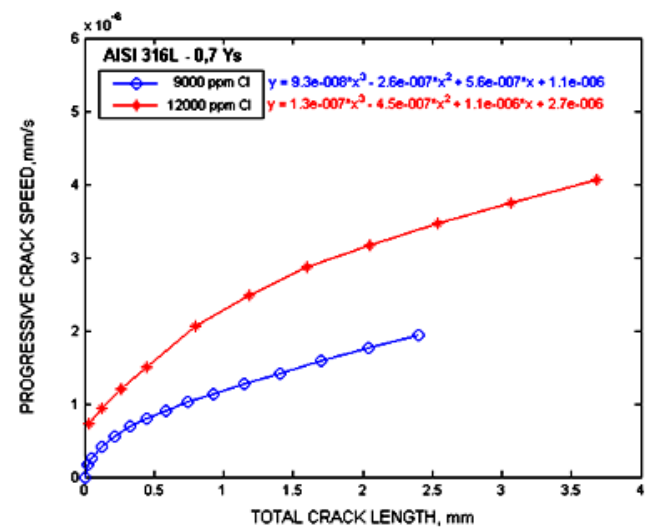


Fig. 5. Correlation curve between Total Crack Length and Progresip Crack Speed SCC AISI 316L (Test Items No. 26 and 28) in different environments with initial stresses 0.7 $\sigma$ Ys.

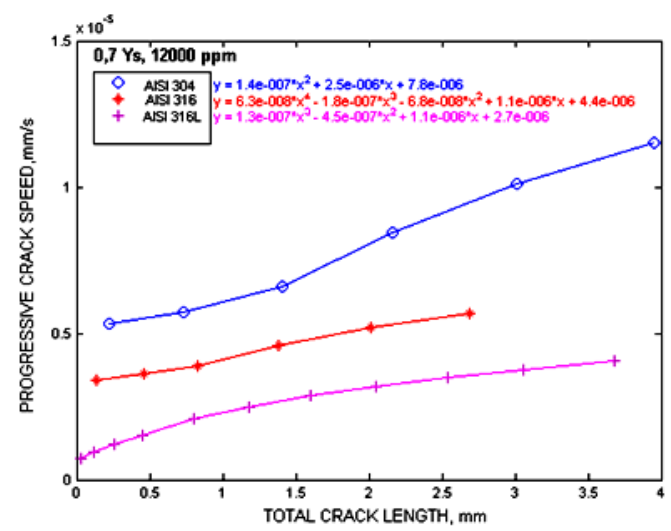

Fig. 6. Correlation curve between Total Crack Length and Progresip Crack Speed with chloride concentration $12000 \mathrm{ppm}$ at $0.7 \sigma$ Ys (specimens No.8, 18 and 28) with different materials

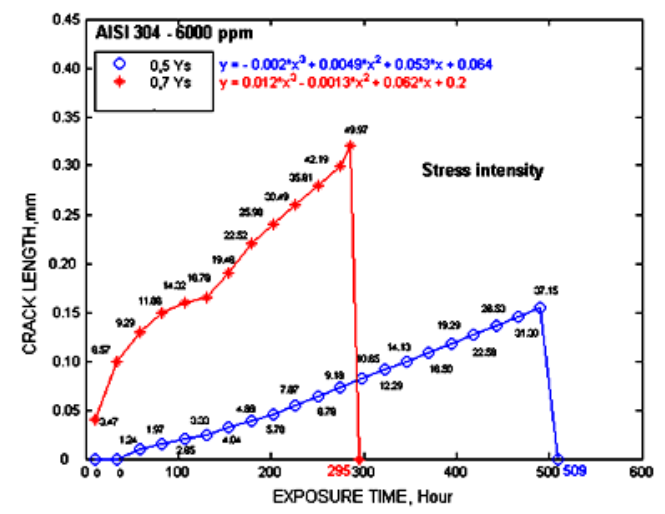

Fig. 7.The correlation curve between the Exposure time and the SCC AISI 304 Crack Length at 6000 ppm (Test Items No. 3 and 4) with different voltages. 


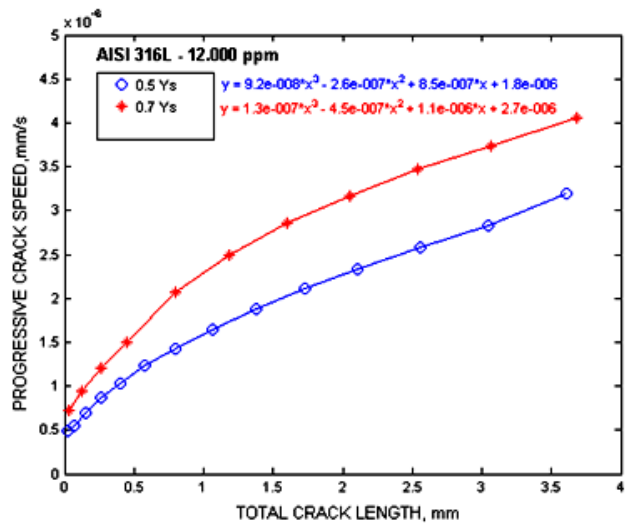

Fig. 8. Correlation curve between Total Crack Length and Progresip SCC AISI 316L Crack Speed at 12000 ppm environment (Test objects No. 27 and 28) with different initial stresses

The measurement of the corrosion rate by using the dye testing method is the basic calculation of commonly used corrosion. The calculation of corrosion rate is based on the ameasurement of weight loss of the specimen at acertin exposure time. Table 7- 9 shows the corrosion rate on all SCC test objects. The corrosion rate obtained in the three tables gives a clear picture of the effect of the environment (Glycerol + Chloride) on certain conditions on the occurrence of SCC on AISI 304, AISI 316, and AISI 316L materials.

Table 5: Corrosion Rate on AISI 304

\begin{tabular}{|c|c|c|c|c|c|c|}
\hline \multirow{2}{*}{$\begin{array}{c}\text { Number } \\
\text { Test } \\
\text { object }\end{array}$} & \multirow{2}{*}{$\begin{array}{c}\text { Concentration } \\
\text { Chloride } \\
(\text { ppm })\end{array}$} & \multirow{2}{*}{$\begin{array}{l}\text { Voltage } \\
\left(\begin{array}{ll}\% & \sigma_{y s}\end{array}\right)\end{array}$} & \multirow{2}{*}{$\begin{array}{c}\text { LongDyeing(hour } \\
\text { ) }\end{array}$} & \multirow{2}{*}{$\begin{array}{l}\text { LoseWeight } \\
\text { (mg) }\end{array}$} & \multicolumn{2}{|c|}{ Corrosion rate } \\
\hline & & & & & mm/year & MPY \\
\hline 11 & 50 & 0,5 & 556 & 1,145 & $6,76 \mathrm{E}-04$ & 0,026 \\
\hline 12 & 50 & 0,7 & 556 & 2,002 & $1,18 \mathrm{E}-03$ & 0,046 \\
\hline 13 & 6000 & 0,5 & 556 & 3,858 & $2,28 \mathrm{E}-03$ & 0,089 \\
\hline 14 & 6000 & 0,7 & 484 & 4,903 & 3,33E-02 & 0,131 \\
\hline 15 & 9000 & 0,5 & 296 & 17,146 & $1,90 \mathrm{E}-02$ & 0,750 \\
\hline 16 & 9000 & 0,7 & 224 & 11,855 & 1,74E-02 & 0,683 \\
\hline 17 & 12000 & 0,5 & 196 & 35,388 & $5,92 \mathrm{E}-02$ & 2,330 \\
\hline 18 & 12000 & 0,7 & 151 & 30,069 & $6,54 \mathrm{E}-02$ & 2,570 \\
\hline
\end{tabular}


Table 6: Corrosion Rate on AISI 316

\begin{tabular}{|c|c|c|c|c|c|c|}
\hline \multirow{2}{*}{$\begin{array}{c}\text { Number } \\
\text { Test } \\
\text { object }\end{array}$} & \multirow{2}{*}{$\begin{array}{l}\text { Concentration } \\
\text { Chloride(ppm) }\end{array}$} & \multirow{2}{*}{$\begin{array}{l}\text { Voltage } \\
\left(\begin{array}{ll}\% & \sigma_{y s}\end{array}\right)\end{array}$} & \multirow{2}{*}{$\begin{array}{l}\text { LongDyeing } \\
\text { (hour) }\end{array}$} & \multirow{2}{*}{$\begin{array}{c}\text { LoseWeight } \\
\text { (mg) }\end{array}$} & \multicolumn{2}{|c|}{ Corrosion rate } \\
\hline & & & & & mm/year & MPY \\
\hline 21 & 50 & 0,5 & 556 & 1,242 & 7,33E-04 & 0,0289 \\
\hline 22 & 50 & 0,7 & 556 & 1,176 & 6,94E-04 & 0,0273 \\
\hline 23 & 6000 & 0,5 & 556 & 3,613 & $2,13 \mathrm{E}-03$ & 0,084 \\
\hline 24 & 6000 & 0,7 & 556 & 3,190 & $1,88 \mathrm{E}-03$ & 0,074 \\
\hline 25 & 9000 & 0,5 & 556 & 15,465 & $9,13 \mathrm{E}-03$ & 0,361 \\
\hline 26 & 9000 & 0,7 & 363 & 15,671 & 1,42E-02 & 0,558 \\
\hline 27 & 12000 & 0,5 & 320 & 13,267 & $1,36 \mathrm{E}-02$ & 0,536 \\
\hline 28 & 12000 & 0,7 & 268 & 18,331 & $2,25 \mathrm{E}-02$ & 0,885 \\
\hline
\end{tabular}

Table 7: Corrosion Rate on AISI 316L

\begin{tabular}{|c|c|c|c|c|c|c|}
\hline \multirow{2}{*}{$\begin{array}{c}\text { Number } \\
\text { Test } \\
\text { object }\end{array}$} & \multirow{2}{*}{$\begin{array}{l}\text { Concentration } \\
\text { Chloride(ppm) }\end{array}$} & \multirow{2}{*}{$\begin{array}{l}\text { Voltage( } \\
\left.\% \sigma_{\mathrm{ys}}\right)\end{array}$} & \multirow{2}{*}{$\begin{array}{l}\text { LongDyein } \\
\text { g (hour) }\end{array}$} & \multirow{2}{*}{ LoseWeight(mg) } & \multicolumn{2}{|c|}{ Corrosion rate } \\
\hline & & & & & $\begin{array}{c}\mathrm{mm} / \mathrm{yea} \\
\mathbf{r}\end{array}$ & MPY \\
\hline 21 & 50 & 0,5 & 556 & 1,242 & $7,33 \mathrm{E}-04$ & 0,0289 \\
\hline 22 & 50 & 0,7 & 556 & 1,176 & $6,94 \mathrm{E}-04$ & 0,0273 \\
\hline 23 & 6000 & 0,5 & 556 & 3,613 & 2,13E-03 & 0,084 \\
\hline 24 & 6000 & 0,7 & 556 & 3,190 & $1,88 \mathrm{E}-03$ & 0,074 \\
\hline 25 & 9000 & 0,5 & 556 & 15,465 & $9,13 \mathrm{E}-03$ & 0,361 \\
\hline 26 & 9000 & 0,7 & 363 & 15,671 & $1,42 \mathrm{E}-02$ & 0,558 \\
\hline 27 & 12000 & 0,5 & 320 & 13,267 & $1,36 \mathrm{E}-02$ & 0,536 \\
\hline 28 & 12000 & 0,7 & 268 & 18,331 & $2,25 \mathrm{E}-02$ & 0,885 \\
\hline
\end{tabular}

According to, the corrosion rate is said to be critical to a material when the MPY value is $\geq 50$ ( $\geq 1 \mathrm{~mm} /$ year). The corrosion rate value obtained in the above Table does not reach the critical value but the material fails. This shows that the effect of stress has a dominant influence on SCC corrosion failure on a material.

The corrosion rate occurring as shown in Table 7 - 9 above also proves that a higher AISI 304 vulnerability level under these test conditions. The difference in average corrosion rates of AISI 304 to AISI 316 and 316L are $75 \%$ and $92 \%$ faster respectively. This proves the resilience of AISI 316L and 316 against higher pitting attacks.According to this proves that the presence of Mo strains owned by AISI 316 and 316L increases the resistance of stainless steel austenite to corrosion attack.

The corrosion resistance of AISI 316L is also driven by low $\mathrm{C}$ content $(0.025 \%)$, while AISI 316 has a C content similar to AISI $304(0.08 \%)$ but Mo content owned by AISI 316 makes this material relatively better resistant to corrosion attack. 


\section{Conclusions}

The results of this study provide the following conclusions:

a) SCC testing with 50 ppm chloride concentration conditions indicated that AISI 304, 316, and $316 \mathrm{~L}$ did not fail with exposure time of 556 hours to a voltage of 0.7 бys.

b) SCC test with $6000 \mathrm{ppm}$ test condition gives result:

- AISI 304 material fails on both types of loading.

- AISI 316 material fails only for 0.7 oysvoltage ..

- AISI 316L does not fail for both types of loading.

c) SCC test with 9000 ppm test condition gives result:

- AISI 304 material fails on both types of loading.

- AISI 316 material fails on both types of loading.

- AISI 316L fails only for 0.7 oys voltage.

d) SCC testing with $12000 \mathrm{ppm}$ test conditions gives the result that the three types of materials fail.

e) Figure 3 - 4curve shows that at higher concentration of chloride will result in the material of the test having shorter failure time, crack speed and faster corrosion rate and wider crack opening.

f) Figure 5 - 6 curve shows that the AISI 316L Failure time material is relatively longer compared toAISI 304 and AISI 316L, and AISI 304 has shorter failure time. AISI 316L crack speed material is slower compared to AISI 304 and AISI 316, and AISI 304 has faster crack speed. The average corrosion rate comparison of AISI 304 to AISI 316 and 316L were $75 \%$ and $92 \%$ faster respectively. This proves the resilience of AISI 316L and AISI 316 against better pitting attacks. AISI 304 has a shorter average failure time, ie AISI 304 failure time against AISI 316 and 316L are $51.44 \%$ and $137.51 \%$, respectively, while AISI 316 against AISI $316 \mathrm{~L}$ is $67.37 \%$.

g) Figure 7 - 8 curve shows that the test material tested at 0.7 oys initial voltage has shorter failure time and faster crack speed.

h) SCC crack model that occurs in the test material is on the grain (transgranular) with brittle fracture fracture.

\section{Suggestion}

SCC failure is strongly influenced by stress, environment, and material structure where the combination of these three factors are synergized, leading to SCC failure. Based on the results of this study and to avoid the occurrence of failures on similar materials in use, the following points need to be considered:

a) Perform actual load calculations on a construction or components made of stainless steel austenite to obtain the amount of voltage that occurs.

b) In the condition of Glycerol solution containing concentration of $50 \mathrm{ppm}$ chloride, a voltage of 0.5 бys, 150 0C AISI 304 material temperature may be used, but if the voltage of 0.7 oys should use AISI 316.SCC failure is strongly influenced by stress, environment, and material structure where the combination of these three factors are synergized, leading to SCC failure. Based on the results of this study and to avoid the 
occurrence of failures on similar materials in use, the following points need to be considered:

a) Perform actual load calculations on a construction or components made of stainless steel austenite to obtain the amount of voltage that occurs.

b) In the condition of Glycerol solution containing concentration of $50 \mathrm{ppm}$ chloride, a voltage of $0.5 \sigma y s, 150$ 0C AISI 304 material temperature may be used, but if the voltage of 0.7 бys should use AISI 316.

c) At the condition of Glycerol solution containing the maximum concentration of $6000 \mathrm{ppm}$ chloride, a voltage of $0.5 \sigma \mathrm{ys}, 150 \mathrm{oC}$ of material temperature, AISI 304 can not be used and preferably using AISI 316 . But at $0.7 \sigma y s$ voltage it is better to use AISI $316 \mathrm{~L}$ where this material can be dug up to a chloride concentration of $9000 \mathrm{ppm}$ and a maximum voltage of 0.5 oys.

d) To get the SCC threshold value need to do further research by using variations of temperature and voltage for this material, so it will be more useful especially for the industry.

e). To obtain more precise measurement results, the test equipment used is necessarydeveloped, for example by using a strain gauge or other precision measuring instrument for get stretches strained during the test. The value of strain obtained then will get the amount of voltage changes that occur at any time.

\section{References}

[1]JUNAIDI, "The Effect of Exposuretime on the Crack Length of Austenite AISI 304,316 and 316L Stainless Steel Material with Failure Stress Corrosion Cracking," in WAHANA INOVASI Jurnal Penelitian dan Pengabdian, 2013, pp. 291-298.

[2] T. Siagian, I. Siregar, H. Lubis, T. Tinggi, U. A. Hamzah, and H. Process, "Characteristics of St . 37 Steel Materials with Temperature and Time on Heat Treatment Test using Furnace," Int. J. Innov. Sci. Res. Technol. ( IJISRT ), vol. 3, no. 4, pp. 49-53, 2018.

[3] JUNAIDI, "ANALYSIS THE EFFECT OF AMPER FLOWS ON THE I, V AND X CAPABILITY WITH E6013 ELECTRODE USING STEEL K945," SAINTEK Fak. Tek. UISU MEDAN, vol. 3, no. ISSN No:2355-2395, pp. 353-362, 2016.

[4] J. Junaidi, S. Hestukoro, A. Yanie, J. Jumadi, and E. Eddy, "IMPLEMENTATION ANALYSIS of CUTTING TOOL CARBIDE with CAST IRON MATERIAL S45 C on UNIVERSAL LATHE," in Journal of Physics: Conference Series, 2017, vol. 930, no. 1.

[5] JUNAIDI, "Analysis Process of St.37 Steel Material Characteristics with Temperature and Time in Heat Treatment Test using Furnace," J. UHAMZAH, vol. 08, no. 15, pp. 43-49, 1918.

[6] Indra roza junaidi, weriono, "Process Analysis of High Speed Steel Cutting Calculation (HSS) with S45 C Material On Universal Machine Tool," IJISRT (International J. Innov. Sci. Res. Technol., vol. 3, no. 1, pp. 447-456, 2018.

[7] J. Weriono, "Noise Analysis of Variations in Engine Turn on 1300 CC Cars Due to Mechanical Vibration," J. Technol. Harapan, vol. 6, no. 1, pp. 7-10, 2017.

[8] JUNAIDI, "Analyze cutting tools (HSS) with cast iron material on Universal Lathes," in Makalah PEKAN ILMIAH Periode XXII-TA.2014/2015 FAKULTAS TEKNIK UISU, 2015, pp. 51-58.

[9] Indra roza, junaidi, weriono, "Irrigation Water Debit Analysis that will be used on Micro Power Plant in SEI . Rampah Sub-District of Serdang Bedagai Regency," Int. J. Innov. Sci. Res. Technol., vol. 3, no. 1, 2018.

[10] JUNAIDI dan EDDY, "Analysis of Cutting Carbide Tools with S45C Material on Universal Lathes," in Seminar Nasional FT.UISU, 2017, pp. 116-123.

[11] S. H. junaidi, weriono, indra roza, "Economic Planning Analysis of MHP PLTMH Using Pico- 
hydro Turbine: Hundreds of watts - 5 KW," IJISRT (International J. Innov. Sci. Res. Technol., vol. 3 , no. 2, pp. 112-116, 2018.

[12] Junaidi, "Tu 3a Cnc Milling Machine Implementation Using Keller Q Cnc Software Based on Auto Cad 2000 Software," in Seminar Nasional Teknologi Informasi dan Komunikasi (SNASTIKOM) HARAPAN, 2017, pp. 349-356.

[13] J. BUDI SANTRI KUSUMA, "Analysis of the effect of cooling media and heating on hardness and microstructure in the tempering process of SKD 11 tool steel.," PROSIDING Seminar Nasional Pembangunan Berkelanjutan Bangsa Berbasis Iptek (PB3I-ITM). BIRO PUBLIKASI DAN DOKUMENTASI -ITM jLN.Gedung Arca No.52 Medan, MEDAN, pp. 63-67, 2014. 